\title{
HUBUNGAN DISIPLIN DAN MOTIVASI BELAJAR TERHADAP HASIL BELAJAR IPA PESERTA DIDIK KELAS IV SDN SEKECAMATAN KEBUMEN TAHUN AJARAN 2020/2021
}

\author{
Tri Yuniantari Redyoningrum ${ }^{1}$, Kartika Chrysti Suryandari², Tri Saptuti Susiani ${ }^{3}$ \\ Universitas Sebelas Maret \\ tyuniantari@student.uns.ac.id
}

Article History

accepted 30/8/2021

approved 30/9/2021

published 30/10/2021

\begin{abstract}
The research aimed to determine positive correlation between learning self-discipline and learning motivation on natural science learning outcomes to fourth grade students of public elementary schools in Kebumen Sub-district in academic year of 2020/2021. The research was correlation quantitative research method. The research population were 1400 fourth grade students and the samples were 320 students. The sampling method used probability sampling technique of random sampling. The data collection methods were questionnaires and tests. The validity method was the empirical method with question analysis technique using Pearson correlation analysis. Reliability used the Alpha (Cronbach's) formula. Prerequisite analysis test included normality test, linearity test, and multicollinearity test. The data analysis technique used the multiple correlation analysis technique. The results indicated that the correlation value between learning self-discipline and learning motivation on natural science learning outcomes was 0.356 with a significance value 0.000 less than 0.05 .
\end{abstract}

Keywords: learning self-discipline, learning motivation, natural science learning outcomes

\section{Abstrak}

Penelitian ini bertujuan untuk membuktikan adanya hubungan positif antara disiplin dan motivasi belajar terhadap hasil belajar IPA peserta didik kelas IV SDN se-Kecamatan Kebumen tahun ajaran 2020/2021. Penelitian ini merupakan penelitian kuantitatif dengan metode korelasi. Populasi penelitian adalah berjumlah 1400 peserta didik dan sampel yang diambil berjumlah 320 peserta didik yang dipilih secara acak menggunakan teknik probability sampling jenis random sampling. Metode pengambilan data menggunakan kuesioner angket dan tes. Metode validitas yang dilakukan menggunakan teknik analisis butir soal menggunakan perhitungan dengan analisis korelasi pearson. Reliabilitas dilakukan perhitungannya menggunakan rumus Alpha (Cronbach's). Sebelum dilakukan analisis data terlebih dahulu dilakukan uji prasyarat analisis yang menggunakan uji normalitas, uji linieritas, dan uji multikolinieritas. Teknik analisis data untuk menguji hipotesis adalah dengan teknik analisis korelasi berganda. Hasil penelitian menunjukkan bahwa nilai korelasi antara disiplin belajar dan motivasi belajar terhadap hasil belajar IPA sebesar 0,356 dengan nilai signifikansi yang diperoleh sebesar 0,000 kurang dari 0,05 .

Kata kunci: disiplin belajar, motivasi belajar, hasil belajar IPA 


\section{PENDAHULUAN}

Memasuki abad ke-21 sekarang ini pendidikan Indonesia dihadapkan dengan sejumlah tantangan, tekanan dan peluang yang tentunya berbeda dengan zaman sebelumnya. Dalam menghadapi sejumlah tantangan, tekanan dan peluang untuk meraih kesuksesan peserta didik, maka peserta didik perlu dibekali dengan pendidikan karakter sejak sekolah dasar. Pendidikan karakter yang sedang dan terus diupayakan perkembangannya oleh pemerintah yaitu disiplin (Rachman \& Murniati, 2016: 75). Disiplin sebagai salah satu nilai karakter yang diperlukan dalam mengembangkan keterampilan abad 21. Motivasi juga menjadi perhatian dalam mengembangkan keterampilan abad ke-21 (Zubaidah, 2016: 12). Motivasi ialah hal yang perlu diperhatikan dalam pembelajaran, sebab hasil belajar akan sangat dipengaruhi oleh motivasi dari dalam diri peserta didik (Fadlilah, 2020: 379). Keberhasilan belajar ternyata lebih banyak ditentukan oleh faktor-faktor emosi, antara lain disiplin dan motivasi (Aunurrahman, 2019: 111).

Disiplin merupakan suatu kondisi yang tercipta dan terbentuk melalui proses dari rentetan perilaku yang menunjukkan adanya nilai-nilai ketaatan, kepatuhan, setia, dan keteraturan serta ketertiban (Sugiarto, Suyati, \& Yulianti, 2019: 234). Maria, J. Wantah menyatakan disiplin belajar merupakan salah satu cara untuk membantu peserta didik agar dapat mengembangkan pengendalian dirinya selama kegiatan pembelajaran (Salam \& Anggraini, 2018: 127). Membiasakan hidup disiplin, apalagi disiplin dalam belajar pada diri peserta didik terdapat faktor yang memengaruhinya antara lain sumber belajar, pendidikan orang tua dan peserta didik itu sendiri, sehingga peserta didik juga memegang peranan dalam mencapai tujuan pendidikan (Amrizal, Aspin, \& Arifyanto, 2020: 78). Usaha yang dapat dilakukan dalam mencapai tujuan pendidikan salah satunya yaitu membiasakan disiplin belajar bagi peserta didik. Dengan disiplin belajar peserta didik yang taat dan patuh terhadap peraturan dalam kegiatan pembelajaran yang diharapkan dapat meningkatkan keberhasilan belajarnya untuk mencapai hasil belajar yang optimal. Berdasarkan uraian tersebut dapat disimpulkan disiplin belajar adalah proses usaha seseorang dalam memperoleh konsep, pemahaman, dan pengetahuan baru yang memengaruhinya dalam berperilaku dengan mematuhi aturan, norma, dan tata tertib secara sadar yang tercipta dan terbentuk sebagai hasil pengalaman peserta didik dalam berinteraksi dengan lingkungannya.

Motivasi merupakan keadaan mental dan sikap individu dengan memberikan kekuatan untuk mendorong individu dalam berusaha mengatasi segala hal yang menjadi tugasnya sehingga diharapkan memperoleh hasil yang optimal. Motivasi didefiniskan sebagai daya penggerak di dalam diri peserta didik yang dapat menumbuhkan keinginan dalam kegiatan belajar, yang menjamin atas terjadinya kegiatan belajar dan memberikan arah pada kegiatan belajar (Lusiana, Poerwanti, \& Matsuri, 2019: 73). Motivasi belajar merupakan perubahan perilaku dari dalam diri seseorang yang ditandai dengan munculnya perasaan dan diawali dengan tanggapan terhadap adanya tujuan (Sardiman, 2016: 73). Motivasi belajar dapat terlihat pada diri peserta didik ditandai dengan peserta didik memperoleh hasil belajar yang baik dengan berkembangnya intensitas belajar dan membentuk kebiasaan belajar yang baik ditandai dengan adanya belajar yang teratur (Djamarah \& Syaiful, 2015: 156). Berdasarkan penjelasan di atas dapat disimpulkan bahwa motivasi belajar adalah daya penggerak atau dorongan yang berasal dari dalam diri peserta didik untuk menggerakkan, mengaktifkan, menyalurkan dan mengarahkan perilakunya dalam memperoleh keberhasilan belajar.

Keberhasilan belajar peserta didik menjadi tolak ukur dalam mengetahui seberapa jauh peserta didik menguasai kompetensi yang diajarkan. Semakin tinggi nilai hasil belajar yang dimiliki oleh peserta didik maka akan semakin baik pula keberhasilan pendidikan yang dilakukan. Hasil belajar adalah kemampuan keterampilan dan sikap yang diperoleh peserta didik setelah menerima perlakuan yang diberikan oleh guru 
sehingga dapat mengkontruksikan pengetahuan itu dalam kehidupan sehari-hari (Meliyana, Herimanto, \& Akhmad, 2019: 76). Hasil belajar merupakan suatu perubahan perilaku seseorang sebagai akibat proses belajar yang dilakukan (Purwanto, 2014: 46). IPA di sekolah dasar adalah mata pelajaran wajib yang memiliki fungsi sebagai alat untuk mengembangkan diri seseorang dalam berbagai kemampuan yang meliputi aspek kepribadian, teknologi, kreatif, inovatif, dan ilmu pengetahuan (Mujakir, 2015: 83).

Berdasarkan uraian tersebut, peneliti melakukan penelitian bertujuan untuk membuktikan ada atau tidaknya hubungan positif dan signifikan antara disiplin belajar dan motivasi belajar terhadap hasil belajar IPA peserta didik kelas IV SDN seKecamatan Kebumen tahun ajaran 2020/2021.

\section{METODE}

Penelitian ini adalah penelitian kuantitatif dengan metode korelasional. Metode yang digunakan dalam penelitian ini bertujuan untuk mengetahui hubungan antara kedua buah variabel dependen dengan satu buah variabel independen. Populasi dalam penelitian adalah seluruh peserta didik kelas IV SDN se-Kecamatan Kebumen tahun ajaran 2020/2021. Sampel penelitian dihitung dengan menggunakan rumus random sampling. Melalui perhitungan tersebut menghasilkan 320 peserta didik kelas IV dari tiga belas sekolah dasar negeri di Kecamatan Kebumen sebagai sampel penelitian.

Teknik pengumpulan data dilakukan dengan menggunakan instrumen angket dan tes. Angket digunakan untuk mengumpulkan data variabel bebas atau variabel dependen yaitu disiplin belajar dan motivasi belajar sedangkan tes digunakan untuk mengumpulkan data variabel terikat atau variabel independen yaitu hasil belajar IPA peserta didik kelas IV SDN se-Kecamatan Kebumen. Selanjutnya, instrumen terlebih dahulu diuji validitas dan reliabilitasnya sebelum akhirnya digunakan dalam penelitian. Pengumpulan data untuk uji instrumen dilakukan pada 41 peserta didik kelas IV SD di dua sekolah yang bukan merupakan sampel.

Teknik analisis data dilakukan dengan uji prasyarat dan uji hipotesis. Pada uji prasyarat penelitian ini dilakukan dengan uji normalitas, linieritas, dan multikolinearitas. Sementara, uji hipotesis dilakukan dengan uji korelasi sederhana, uji korelasi berganda dan perhitungan koefisien determinan.

\section{HASIL DAN PEMBAHASAN}

Deskripsi data merupakan gambaran hasil pengumpulan data dari tiap-tiap variabel yang diteliti. Berdasarkan penelitian yang telah dilakukan, diperoleh data disiplin belajar dan motivasi belajar sebagai variabel bebas dan data hasil belajar IPA sebagai varaibel terikat. Data tentang variabel disiplin dan motivasi belajar diperoleh dengan menyebar angket kepada peserta didik kelas IV sedangkan data tentang variabel hasil belajar diperoleh dengan menyebar soal tes kepada peserta didik kelas IV SD. Sebelum digunakan dalam penelitian, angket terlebih dahulu diuji kevalidannya dengan cara dikonsultasikan kepada dosen pembimbing dan diujikan pada 41 peserta didik yang bukan sampel penelitian dan dianalisis menggunakan aplikasi SPSS. Jumlah pernyataan angket dan tes yang valid dan akan diujikan pada 320 peserta didik yang menjadi sampel penelitian. Data yang diperoleh kemudian dimasukan dalam MS. Excel dan dianalisis menggunakan aplikasi SPSS.

Tabel 1.1 Hasil Analisis Deskriptif Variabel Data Penelitian 


\begin{tabular}{lccc}
\hline Statistik Deskriptif & Disiplin Belajar $\left(\mathrm{X}_{1}\right)$ & Motivasi Belajar $\left(\mathrm{X}_{2}\right)$ & Hasil Belajar IPA $(\mathrm{Y})$ \\
\hline N Sampel & 320 & 320 & 320 \\
Mean & 81.51 & 79.52 & 54.69 \\
Median & $82.00^{\mathrm{a}}$ & $80.28^{\mathrm{a}}$ & $54.49^{\mathrm{a}}$ \\
Mode & 81 & 80 & 54 \\
\hline
\end{tabular}

Berdasarkan hasil analisis pada tabel 1.1, dapat dilihat bahwa rata-rata data skor angket disiplin belajar peserta didik yaitu 81,51. Nilai tengah data disiplin belajar sebesar 82,00. Nilai yang sering muncul dalam data disiplin belajar peserta didik adalah 81. Kecenderungan nilai yang hampir sama antara nilai rata-rata, nilai tengah dan nilai yang sering muncul menandakan bahwa data disiplin belajar memiliki kurva yang simetris dan berdistribusi normal. Hal tersebut sejalan dengan pendapat Abdurahman, Muhidin, dan Somantri (2011: 120) yang berpendapat bahwa apabila suatu data memiliki nilai rata-rata, nilai tengah dan nilai yang sering muncul yang sama maka data tersebut berdistribusi normal.

Dari hasil analisis pada tabel 1.1 dapat diketahui bahwa rata-rata data skor angket motivasi belajar peserta didik sebesar 79,52. Nilai tengah data motivasi belajar adalah 80,28 . Nilai yang sering muncul dalam data motivasi belajar peserta didik yaitu 80 . Kecenderungan nilai yang hampir sama antara nilai rata-rata, nilai tengah dan nilai yang sering muncul menandakan bahwa data motivasi belajar memiliki kurva yang simetris dan berada pada distribusi normal.

Dari tabel 1.1 di atas dapat diketahui bahwa rata-rata skor hasil belajar IPA peserta didik yaitu 54,69. Nilai tengah data hasil belajar IPA adalah 54,69. Nilai yang sering muncul dalam data hasil belajar IPA peserta didik adalah 54 . Kecenderungan nilai yang hampir sama antara nilai rata-rata, nilai tengah, dan nilai yang sering muncul menandakan bahwa data hasil belajar IPA peserta didik kelas IV SD memiliki kurva yang simetris dan berdistribusi normal.

Uji normalitas digunakan untuk mengetahui apakah data dalam penelitian berdistribusi normal atau tidak. Dari data yang diperoleh kemudian diuji normalitas menggunakan uji Kolmogorov-Smirnov dengan menggunakan bantuan SPSS versi 21. Kriteria pengambilan keputusan yaitu jika signifikansi $>0,05$ maka data berdistribusi normal, sedangkan jika signifikansi $<0,05$ maka data berdistribusi tidak normal (Prayitno, 2013: 36).

Tabel 1.2 Hasil Analisis Uji Normalitas Data

\begin{tabular}{lccl}
\hline & Kolmogorov-Smirnov & Df & Sig. \\
\hline Disiplin Belajar & 1.073 & 320 & .200 \\
Motivasi Belajar & 1.072 & 320 & .201 \\
Hasil Belajar IPA & 0.850 & 320 & .465 \\
\hline
\end{tabular}

Berdasarkan hasil uji normalitas melihat nilai Asymp. Sig. (2-tailed) dapat diketahui bahwa nilai signifikansi variabel disiplin belajar diperoleh sebesar 0,200. Dapat dilihat bahwa nilai signifikansi disiplin belajar lebih besar dari 0,05 yang artinya variabel disiplin belajar berdistribusi normal sehingga dapat dilakukan uji hipotesis. Pada variabel motivasi belajar diperoleh nilai signifikansi sebesar 0,201. Dapat dilihat bahwa nilai signifikansi motivasi belajar lebih besar dari 0,05 yang artinya variabel motivasi belajar berada pada distribusi normal dan variabel hasil belajar diperoleh 0,465 lebih besar dari 0,05 sehingga berdasarkan hasil analisis ketiga variabel tersebut nilai 
signifikansi lebih besar dari 0,05, yang menunjukkan bahwa data variabel disiplin belajar, motivasi belajar dan hasil belajar IPA berdistribusi normal.

Uji linieritas merupakan uji asumsi apakah terdapat hubungan antarvariabel dalam bentuk garis lurus atau tidak. Data dikatakan linier $p$ value deviation from linierity > 0,05 . Berdasarkan uji linieritas yang telah dilakukan pada variabel disiplin belajar dan hasil belajar IPA diperoleh $p$ value deviation from linierity sebesar 0,333 . Berdasarkan hasil analisis tersebut dapat dilihat bahwa $p$ value deviation from linierity lebih besar dari 0,05 maka dapat diketahui bahwa antara disiplin belajar dengan hasil belajar terdapat hubungan yang linier. Pada variabel motivasi belajar dan hasil belajar IPA diperoleh $p$ value deviation from linierity sebesar 0,803 . Dari hasil analisis tersebut dapat dilihat bahwa $p$ value deviation from linierity lebih besar dari 0,05 maka dapat diketahui bahwa antara variabel disiplin belajar dengan hasil belajar terdapat hubungan yang linier. Dengan demikian dapat diketahui bahwa $p$ value deviation from linierity antara masing-masing variabel bebas dan variabel terikat $>0,05$. Artinya terdapat hubungan yang linier antara variabel disiplin belajar dengan variabel hasil belajar IPA dan terdapat hubungan yang linier antara variabel motivasi belajar dengan hasil belajar IPA.

Uji multikoliniearitas merupakan uji yang dilakukan untuk mengetahui ada tidaknya multikoliniearitas dalam variabel bebas pada penelitian ini yaitu variabel disiplin belajar dan variabel motivasi belajar. Untuk mengetahui hubungan multikoliniear pada penelitian ini, yaitu dengan melihat nilai tolerance dan VIF. Apabila VIF di bawah 10 dan nilai tolerance di atas 0,10 dan nilai keduanya mendekati 1 artinya tidak terjadi hubungan multikoliniearitas maka antar variabel bebas yang digunakan terlepas dari permasalahan multikoliniearitas.

Tabel 1.3 Hasil Analisis Uji Multikoliniearitas Data

\begin{tabular}{lcc}
\hline \multicolumn{1}{c}{ Model } & \multicolumn{2}{c}{ Collinearity Statistics } \\
\cline { 2 - 3 } Disiplin Belajar & Tolerance & VIF \\
Motivasi Belajar & .923 & 1.083 \\
\hline
\end{tabular}

Berdasarkan hasil uji multikoliniearitas yang telah dilakukan diperoleh nilai tolerance sebesar 0,923>0,10 dan nilai VIF sebesar 1,083<10,00 dan keduanya mendekati nilai 1. Hal tersebut berarti tidak terjadi hubungan multikoliniearitas antara variabel disiplin belajar dan motivasi belajar.

Analisis uji korelasi ganda digunakan untuk mengetahui hubungan antara dua atau lebih variabel independen terhadap variabel dependen secara bersma-sama. Koefisien ini menunjukkan seberapa besar hubungan yang terjadi antara variabel independen dengan variabel dependen. Hasilnya dapat dilihat sebagai berikut:

Tabel 1.4 Hasil Analisis Uji korelasi berganda

\begin{tabular}{ccccc}
\hline Ket & $\mathrm{R}$ & $\begin{array}{c}\mathrm{R} \\
\text { Square }\end{array}$ & $\begin{array}{c}\text { Adjusted } \mathrm{R} \\
\text { Square }\end{array}$ & $\begin{array}{c}\text { Std. Error of } \\
\text { the Estimate }\end{array}$ \\
\hline $\begin{array}{c}\mathrm{X} \text { 1 dan } \mathrm{X} 2 \\
\text { dengan } \mathrm{Y}\end{array}$ & .356 & .127 & .121 & 19.427 \\
\hline
\end{tabular}


Berdasarkan hasil yang telah diperoleh dalam uji korelasi berganda yang telah dilakukan, maka koefisien korelasi antara disiplin belajar dan motivasi belajar terhadap hasil belajar IPA sebesar 0,356 bertanda positif dengan kriteria sedang. Kemudian, uji korelasi yang telah dilakukan menunjukkan nilai signifikansi (2-tailed) sebesar $0,000<0,05$ yang berarti bahwa Ho ditolak, artinya ada korelasi antara variabel disiplin belajar dan motivasi belajar terhadap hasil belajar IPA peserta didik kelas IV SD seKecamatan Kebumen. Selanjutnya, kontribusi variabel disiplin belajar dan motivasi belajar terhadap hasil belajar IPA sebesar 12,1\%. Hal itu berarti disiplin belajar dan motivasi belajar secara bersama-sama memberi pengaruh sebesar $12,1 \%$ terhadap hasil belajar IPA peserta didik kelas IV SD dan sisanya $87,9 \%$ dipengaruhi oleh variabel lain diluar variabel yang diteliti seperti kecerdasan peserta didik dan lingkungan keluarga. Kecerdasan pada setiap peserta didik berbeda-beda dengan kecerdasan yang dimiliki peserta didik pada umumnya mudah belajar dan hasil belajar yang diperolehnya cenderung baik. Faktor lingkungan keluarga memiliki pengaruh dalam memberikan perhatian dan membuat peserta didik merasa nyaman dan aman dalam belajar sehingga memberikan kontribusi yang baik dalam meningkatkan hasil belajarnya. Jika disiplin belajar dan motivasi belajar telah ada di dalam diri peserta didik maka semua itu akan memberikan kesadaran dan dorongan untuk memiliki kemauan untuk mengoptimalkan hasil belajar yang ingin dicapai. Disiplin belajar dan motivasi belajar sangatlah penting bagi peserta didik, karena akan mendorong peserta didik untuk dapat memperoleh hasil belajar yang lebih baik, sehingga peserta didik akan berusaha untuk giat dalam belajar. Dengan adanya disiplin belajar yang baik dan diiringi dengan motivasi, dapat membentuk pola belajar yang lebih teratur dan terarah sehingga hasil belajar akan menjadi optimal. Dengan demikian untuk meningkatkan hasil belajar IPA peserta didik dilakukan dengan memperbaiki disiplin belajar dan meningkatkan motivasi belajar peserta didik. Berdasarkan hal tersebut dapat diketahui bahwa terdapat hubungan yang signifikan antara disiplin dan motivasi belajar secara bersama-sama dengan hasil belajara IPA peserta didik kelas IV SD. Hal tersebut relevan dengan penelitian yang dilakukan oleh Siti Nur \& Sumilah (2018) yang menyatakan bahwa terdapat hubungan yang signifikan antara disiplin belajar dan motivasi belajar dengan hasil belajar peserta didik. Penelitian lain oleh Nopi Damayanti (2019) ada hubungan yang signifikan antara disiplin belajar dan motivasi belajar dengan hasil belajar peserta didik dan sesuai dengan hipotesis yang diajukan pada penelitian ini yaitu ada hubungan yang signifikan antara disiplin belajar dan motivasi belajar terhadap hasil belajar IPA peserta didik kelas IV SDN se-Kecamatan Kebumen.

\section{SIMPULAN}

Berdarakan hasil penelitian mengenai disiplin belajar, motivasi belajar dan hasil belajar IPA peserta didik kelas IV SD dapat ditarik kesimpulan bahwa terdapat hubungan yang signifikan antara disiplin belajar dan motivasi belajar secara bersamasama terhadap hasil belajar IPA peserta didik kelas IV SD yang ditunjukkan dengan koefisien korelasi sebesar 0,356 berada pada kriteria sedang.

\section{DAFTAR PUSTAKA}

Amrizal, A., Aspin, \& Arifyanto, A. (2020). Hubungan Motivasi Belajar dengan Disiplin Belajar Siswa. Jurnal Bening, 4(1), 77-86.

Aunurrahman. (2019). Belajar dan Pembelajaran. Bandung: Alfabeta.

Damayanti, N. (2019). Hubungan Disiplin Belajar dan Motivasi Belajar dengan Hasil Belajar Matematika Peserta Didik Kelas V SDN 6 Kelapa Tujuh. Jurnal Unila, 1(3). 1-12.

Djamarah \& Syaiful, B. (2015). Psikologi Belajar. Jakarta: Rineka Cipta. 
Fadlilah, A. (2020). Strategi Menghidupkan Motivasi Belajar Anak Usia Dini Selama Pandemi Covid-19 melalui Publikasi. Jurnal Pendidikan Anak Usi Dini, 5(1), 373-384.

Mujakir. (2015). Kreativitas Guru Dalam Pembelajaran IPA di Sekolah Dasar. Jurnal Lantanida, 03(01).

Purwanto. (2014). Evaluasi Hasil belajar. Yogyakarta: Pustaka Pelajar.

Lusiana, N., Poerwanti \& Matsuri. (2019). Hubungan antara Motivasi dan Disiplin Belajar dengan Keterampilan Berpikir Kritis IPS Interaksi Manusia dengan Lingkungan dan Pengaruhnya Kelas V SD. Jurnal Candi, 10(2), 70-83.

Meliyana, E., Herimanto \& Akhmad, A. (2019). Hubungan Antara Pemanfaatan Fasilitas Belajar dan Disiplin Belajar dengan Hasil belajar Sejarah Siswa kelas X SMK Veteran 1 Sukoharjo Tahun Ajaran 2017/2018. Jurnal Candi, 19(2), 72-85.

Nur, S., \& Sumilah. (2018). Hubungan Motivasi Belajar Dan Disiplin Belajar Terhadap Hasil Belajar PKn. Jurnal Kreatif, 9(1). 12-20.

Sugiarto, A., Suyati, T., \& Yulianti, P. (2019). Faktor Kedisiplinan Belajar Pada Siswa Kelas X SMK Larenda Brebes. Jurnal Mimbar Ilmu, 24(2), 234.

Salam, M., \& Anggraini, I. (2018). Kedisiplinan Belajar Siswa Kelas V di SDN 55/l Sridadi. Jurnal Gentala Pendidikan Dasar, 3(1), 127-144.

Sardiman, A. M. (2016). Interaksi Dan Motivasi Belajar Mengajar. Depok: Rajagrafindo Persada.

Rachman, A., \& Murniati, A. (2016). Meningkatkan Kedisiplinan Siswa Melalui Pengelolaan Kelas di SDN 23 Pagi Palmerah Jakarta. Jurnal Perkotaan, 8(2), 75-93.

Zubaidah, S. (2016). Pendidikan Karakter Terintegrasi Keterampilan Abad Ke-21. Jurnal Penelitian Dan Pengkajian IImu Pendidikan, 3(2), 1-2. 